\title{
Effects of different compost amendments on the abundance and composition of alkB harboring bacterial communities in a soil under industrial use contaminated with hydrocarbons
}

\author{
Stefanie Wallisch ${ }^{1}$, Tjasa Gril' ${ }^{1}$ Xia Dong ${ }^{1}$, Gerd Welzl ${ }^{1}$, Christian Bruns ${ }^{2}$, Ester Heath ${ }^{3}$, \\ Marion Engel ${ }^{1}$, Marjetka Suhadolc ${ }^{4}$ and Michael Schloter ${ }^{1 *}$
}

${ }^{1}$ Research Unit Environmental Genomics, Helmholtz Zentrum München, Munich, Germany

2 Organic Agricultural Sciences, University of Kassel, Witzenhausen, Germany

${ }^{3}$ Jožef Stefan Institute, Ljubljana, Slovenia

${ }^{4}$ Biotechnical Faculty, Center for Soil and Environmental Science, University of Ljubljana, Ljubljana, Slovenia

\section{Edited by:}

Paul Bodelier, Netherlands Institute of Ecology (NIOO-KNAW),

Netherlands

Reviewed by:

Paul Bodelier, Netherlands Institute of Ecology (NIOO-KNAW),

Netherlands

Guy Charles Abell, CSIRO, Australia

*Correspondence:

Michael Schloter, Helmholtz

Zentrum München Deutsches

Forschungszentrum für Gesundheit und Umwelt $(\mathrm{GmbH})$, Ingolstädter Landstraße 1, 85764 Neuherberg,

Germany

e-mail: schloter@helmholtzmuenchen.de
Alkane degrading microorganisms play an important role for the bioremediation of petrogenic contaminated environments. In this study, we investigated the effects of compost addition on the abundance and diversity of bacteria harboring the alkane monooxygenase gene $(a / k B)$ in an oil-contaminated soil originated from an industrial zone in Celje, Slovenia (Technosol). Soil without any amendments (control soil) and soil amended with two composts differing in their maturation stage and nutrient availability, were incubated under controlled conditions in a microcosm experiment and sampled after $0,6,12$, and 36 weeks of incubation. As expected the addition of compost stimulated the degradation of alkanes in the investigated soil shortly after the addition. By using quantitative real-time PCR higher number of alkB genes were detected in soil samples amended with compost compared to the control soils. To get an insight into the composition of alkB harboring microbial communities, we performed next generation sequencing of amplicons of alkB gene fragment. Richness and diversity of alkB gene harboring prokaryotes was higher in soil mixed with compost compared to control soils with stronger effects of the less maturated, nutrient poor compost. The phylogenetic analysis of communities suggested that the addition of compost stimulated the abundance of alkB harboring Actinobacteria during the experiment independent from the maturation stage of the compost. AlkB harboring $\gamma$-proteobacteria like Shewanella or Hydrocarboniphaga as well as $\alpha$-proteobacteria of the genus Agrobacterium responded also positively to the addition of compost to soil. The amendment of the less maturated, nutrient poor compost resulted in addition in a large increase of alkB harboring bacteria of the Cytophaga group (Microscilla) mainly at the early sampling time points. Our data indicates that compost amendments significantly change abundance and diversity pattern of alkB harboring microbes in Technosol and might be a useful agent to stimulate bioremediation of hydrocarbons in contaminated soils.

Keywords: alkane monooxygenase alkB, compost, contaminated soils, bioremediation, next generation sequencing

\section{INTRODUCTION}

Since almost 150 years industry has been using petroleum-based products as major source of energy (OPEC, 2012). Therefore, the number of industrialized as well as remote areas that show a serious degree of contamination with substances which derive from petroleum is continuously increasing, as the risk for accidental spills or leaks during oil exploration, the industrial manufacturing processes and transport is high (SOER, 2010). Linear and branched alkanes, cycloalkanes and other aromatic compounds being part of petroleum are then released to the environment and have contaminated soil ecosystems as well as water bodies (Pinedo et al., 2013).
However, alkanes are also naturally produced by many living organisms. Alkane derivatives are for example part of plant waxes (Eglinton et al., 1962), pheromones produced by animals (Mori, 2007) or fungal spores (Oró et al., 1966; Fisher et al., 1972). Thus, many microbes are able to degrade alkanes either as mean of detoxification or as source of energy (Ayala and Torres, 2004). Depending on the length of the carbon chain, different types of alkane hydroxylases have been described so far: Alkanes with one to four carbon residues $\left(\mathrm{C}_{1}-\mathrm{C}_{4}\right)$ are mainly degraded by the methane monooxygenases (Jiang et al., 2010) as well as propane- (Steffan et al., 1997) and butane oxygenases (Dubbels et al., 2007); alkanes with medium chain length $\left(C_{6}-C_{11}\right)$ are 
metabolized by the alkane monooxygenase system (Kloos et al., 2006), which is mainly found amongst bacteria or by the fungal cytochrome P450 enzyme system (Van Beilen and Funhoff, 2005); long chain alkanes $\left(>\mathrm{C}_{20}\right)$ are preferably transformed by LadA and other hydroxylases (Ji et al., 2013). One organism can harbor several alkane degrading enzyme systems that are activated depending on the quality of the alkanes (Rojo, 2009).

Microbes play a very important role in the development of remediation strategies of sites contaminated with alkanes. However, mainly in soils with technical origin (Technosols) the potential to degrade alkanes after a contamination with petroleum is low. This might be a result of the overall low microbial biomass and activity as a consequence of missing nutrients (Scalenghe and Ferraris, 2009). Furthermore, the low levels of natural alkanes due to the spare vegetation cover might have prohibited the development of an alkane degrading microflora in Technosols (Séré et al., 2008). Compost material, which is mainly based on plant derived litter material, contains high numbers of microbes that are capable to degrade hydrocarbons (Keeling et al., 1994). Therefore, in the past it has been investigated in several studies, if the addition of compost material may stimulate the degradation of pollutants like hydrocarbons in Technosols (e.g., Beaudin et al., 1999; Van Gestel et al., 2003). However, despite the often reported positive effects of compost amendments on the degradation of hydrocarbons in Technosols, it is not clear if these positive effects of compost addition are related to the introduced microbes and their genetic potential to degrade alkanes or to a general shift of microbial community structure in soil as a result of extra nutrients provided by the compost.

Therefore, we investigated in this study the role of composts on the abundance and diversity of alkane degrading microbes in an alkane contaminated Technosol in a laboratory study. We used two contrasting types of composts of different maturation stages, which are characterized by contrasting nutrient levels, to investigate the influence of the compost type on the obtained data. Soil samples were taken at selected time points after the amendment of compost to soil. As a model for alkane degraders, microbes where chosen, which carry the alkB gene. This gene codes for a subunit of the bacterial alkane monoxygenase. $A l k B$ harboring microbes have been described on the one hand as major players in the degradation of plant derived alkanes (Giebler et al., 2013) and have been detected also in high numbers in soils contaminated with petroleum or crude oil on the other hand (Andria et al., 2009). Thus, this group of microbes might be of interest, if composts are used to stimulate bioremediation of alkanes in contaminated soils. For the analysis of alkB diversity an amplicon based pyrosequencing pipeline was performed using extracted DNA from the different samples as well as established primer systems. Abundance of alkB harboring bacteria was assessed from the same extracts using the same primers by quantitative real time PCR.

\section{MATERIALS AND METHODS COMPOST AND SOIL MATERIAL}

The composts used in this experiment were differing from each other and composed from yard waste compost and a mix of yard waste and biowaste from separated organic household waste.
While the yard waste type (C1) was mainly based on shredded shrubs and trees the second compost (C2) was consisting of organic kitchen waste (food residues) grass clippings, shredded shrubs and other woody material, vegetable and flower residues. C1 was processed for 1 year at a commercial composting plant in the north of Germany (AHA Hannover-Lahe). Temperature development during the composting period was up to $65^{\circ} \mathrm{C}$. The windrow was turned regularly according to the schedule of the composting plant each week in the first 8 weeks with decreasing frequency in dependence of temperature, water, and oxygen content [not less than 15\% (vol.)]. The compost was stable and typical for this type of yard waste compost in terms of nutrient contents $\left[\mathrm{C}_{\text {org }} 14 \%, \mathrm{~N}_{\text {org }} 1.01 \%\right.$, available (mineral) N 230, P 715,

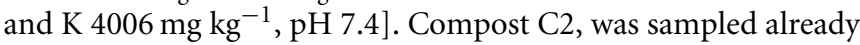
after 2 weeks of composting of a model compost windrow $\left(2 \mathrm{~m}^{3}\right)$ reaching temperature peaks of $72^{\circ} \mathrm{C}$ in this phase of high decomposition. Carbon loss of the raw material in the very early period was fairly high: the starting material had a $\mathrm{C} / \mathrm{N}$-ratio of $41(33.4 \%$ $\mathrm{C}_{\text {org }}, 0.8 \% \mathrm{~N}_{\text {org }}$ ) but after already 14 days of composting the carbon content decreased to $29.3 \%$ and $\mathrm{N}_{\text {org }}$ increased relatively to $0.94 \%$ ( C/N-ratio 31). The heap was turned once after 1 week processing. The available (mineral) nutrients of $\mathrm{C} 2$ were fairly low as expected (N 20.8, P 597 and $\mathrm{K} 3259 \mathrm{mg} \mathrm{kg}^{-1}$, pH 7.6)

The soil, showing the typical features of a Technosol, was sampled up to a depth of $20 \mathrm{~cm}$ from an industry zone in Celje, Slovenia $\left[46.2335^{\circ}(\mathrm{N}), 15.2764^{\circ}(\mathrm{E})\right]$ in June 2009 . The soil has been characterized using ISO referenced standard methods as loamy sand with a $\mathrm{C}_{\text {org }}$ of $8.7 \%$ and a $\mathrm{N}_{\text {tot }}$ of $1.2 \%$. The $\mathrm{pH}$ of the soil was 7.3. The site has been exposed for 150 years of zinc smelting and accompanied chemical industry and it is known for high contamination of soils with hydrocarbons.

\section{SOIL MICROCOSM INCUBATION}

Cylinders made of stainless steel with a diameter of $10 \mathrm{~cm}$ and heights of $13 \mathrm{~cm}$ were used. Thirty-six of these microcosms were hand-packed with $120 \mathrm{~g}$ of fresh, homogenized and $5 \mathrm{~mm}$ sieved soil (which is equivalent to approximately $100 \mathrm{~g} \mathrm{dw}^{-1}$ soil). The field bulk density was adjusted to $1.3 \mathrm{~g} \mathrm{~cm}^{-3}$. After preincubation of all microcosms for 1 week at $14^{\circ} \mathrm{C}$ (reflecting the annual middle temperature of this region) at constant water content [ $80 \%$ of water holding capacity (WHC)], three different treatments were set up: (1) original soil (Soil), which served as a control, (2) soil, mixed with $2.3 \mathrm{~g} \mathrm{dw}^{-1}$ stable compost (soil + $\mathrm{C} 1$ ), and (3) soil mixed with $2.3 \mathrm{~g} \mathrm{dw}^{-1}$ young compost (soil + $\mathrm{C} 2$ ). Composts were added to soil in pots after soil conditioning, and toughly mixed with soil. The control soil was also mixed, however, without any addition of amendments. All pots were covered with perforated cups, and kept at $14^{\circ} \mathrm{C}$ and dark for the whole duration of the experiment. At regular time intervals, aeration and soil water adjustment ( $80 \%$ of WHC) was performed. Sampling was performed at four time points: (i) on the day of experiment set up (week 0), and at (ii) 6 (week 6), (iii) 12 (week 12), and (iv) 36 (week 36) weeks after compost amendment by removing all soil from the microcosm and mixing. Samples of $2 \mathrm{~g}$ were transferred to dry ice immediately after sampling and stored at $-80^{\circ} \mathrm{C}$. For the determination of alkane concentrations, additionally soil samples were taken and air dried. Experiments were 
performed in three replicates for each treatment and sampling time point.

\section{EXTRACTION AND DETERMINATION OF n-ALKANES}

Alkanes were extracted from soil samples by Soxhlet extractor (Barnstead/LAB-LINE multi-unit extracting heater, Labline Thermo Scientific, Dubuque, USA) (EPA 3540C, 1996; http: //www.epa.gov/osw/hazard/testmethods/sw846/pdfs/3540c.pdf). Briefly $1 \mathrm{~g}$ of air-dried sample was mixed with $200 \mu \mathrm{L}$ of internal standard [n-tetracosane-d50 (98\%, $75 \mu \mathrm{g} / \mathrm{mL}$, Cambridge Isotope Laboratories, Andover, MA, USA)], placed into extraction thimble $(30 \times 100 \mathrm{~mm}$, Macherey-Nagel GmbH\&Co. Kg, Düren, Germany) and covered with pre-extracted glass wool (silane untreated, Supelco, Bellefonte, PA, USA). After adding $120 \mathrm{~mL}$ of dichloromethane (J.T. Baker, Deventer Nederland), samples were Soxhlet extracted at $60^{\circ} \mathrm{C}$ for $16 \mathrm{~h}$. After reducing extract volume under gentle stream of nitrogen, solvent was exchanged to cyclohexane (4 mL, Merck, Darmstadt, Germany) and finally reduced to $1 \mathrm{~mL}$ in volume. A clean-up on silica gel (grade 12, 28-200 mesh, Sigma Aldrich, Saint Louis, USA) followed. The extract containing alkanes was eluted with $25 \mathrm{~mL}$ pentane and reduced in volume to $10 \mathrm{~mL}$. One microliter of sample was injected into gas chromatograph coupled to mass spectrometry detector (HP 6890 Series, Hewlet-Packard, Waldbron, Germany) equipped with Agilent DB-5MS, 30m $\times$ $0.25 \mathrm{~mm} \times 0.25 \mathrm{um}$ capillary column. Temperature program was as follows: initial temperature $40^{\circ} \mathrm{C}$, rate of $8^{\circ} \mathrm{C} / \mathrm{min}$ to do $300^{\circ} \mathrm{C}$ (held for $15 \mathrm{~min}$ ) and carrier gas velocity (He 6.0) was $36 \mathrm{~cm} / \mathrm{s}$. Injector temperature and interface temperature were 250 and $280^{\circ} \mathrm{C}$, respectively. $17 \mathrm{n}$-alkanes TRPH $(500 \mu \mathrm{g} / \mathrm{mL}$ each, Restek, Florida, USA) were used as external standard.

\section{DNA EXTRACTION}

Genomic DNA was extracted from all samples in triplicates $(0.5 \mathrm{~g}$ soil each) using the Fast DNA Spin Kit for Soil (MP Biomedicals, USA) according to the supplier's manual. Extracted DNA was quantified spectro-photometrically with a NanoDrop 1000 device (NanoDrop Technologies, USA) and visualized with agarose gel electrophoresis ( $1 \%$ agarose stained with ethidium bromide).

\section{QUANTITATIVE REAL-TIME PCR OF THE alkB GENE}

A SYBR Green based quantitative real-time PCR were carried out on a 7300 Real-Time PCR System (Applied Biosystems, Germany) using the primer pair alkB-1f $5^{\prime}$-AA YACIGCICAYGARCTIGGICAYAA- $3^{\prime}$ and alkB-1r $5^{\prime}$-GCRTG RTGRTCIGARTGICGYTG-3' (Kloos et al., 2006; Schulz et al., 2012; Giebler et al., 2013). The expected amplicon size was in the range of $550 \mathrm{bp}$. In a preliminary test, dilution series of the DNA extracts were performed to avoid inhibition of PCR, resulting in an optimal dilution of 1:50 for all DNA samples (data not shown). Serial plasmid dilutions (carrying the alkB gene from Pseudomonas putida Gpo1) from $10^{6}$ to $10^{1}$ gene copies $\mu l^{-1}$ served as standard (for details see Schulz et al., 2012). qPCRs were performed in five technical replicates for each sample. The PCR master mix with a total volume of $25 \mu \mathrm{l}$ contained $0.5 \mu 150 \mathrm{mM}$ $\mathrm{MgCl}_{2}, 0.5 \mu \mathrm{l} 10 \mu \mathrm{M}$ alkB specific primers, $0.5 \mu \mathrm{l} 3 \%$ bovine serum albumin, $12.5 \mu$ l Power SYBR Green Master Mix (Applied
Biosystems, Germany) and 2 ng DNA. After a initial denaturation step $\left(10 \mathrm{~min} 95^{\circ} \mathrm{C}\right.$ ) a touchdown PCR was performed ( 5 cycles of $45 \mathrm{~s} 95^{\circ} \mathrm{C}, 1 \mathrm{~min} 62^{\circ} \mathrm{C}$ (stepwise reduced to $57^{\circ} \mathrm{C}$ ) and $45 \mathrm{~s} 72^{\circ} \mathrm{C}$, followed by 40 cycles of $45 \mathrm{~s} 95^{\circ} \mathrm{C}, 1 \mathrm{~min} 57^{\circ} \mathrm{C}$ and $45 \mathrm{~s} 72^{\circ} \mathrm{C}$; final extension was $10 \mathrm{~min}$ at $72^{\circ} \mathrm{C}$ ). Specificity of the amplified products was tested with a melting-curve and a $1 \%$ agarose gel stained with ethidium bromide. The amplification efficiency of $85 \%$ was calculated according to the equation

$$
\mathrm{Eff}=\left[10^{(-1 / \text { slope })}-1\right] * 100
$$

\section{AMPLICON SEOUENCING OF alkB FRAGEMENTS}

For amplicon sequencing the same primer system as described above was used. alkB gene amplicons with unique identifiers each for the forward and reverse strand were sequenced bidirectionally on a 454 GS FLX Titanium platform (Roche, Penzberg, Germany) according the manual for amplicon sequencing provided by Roche. In brief, alkB amplicons were generated in three technical replicates using FastStart High Fidelity PCR System (Roche, Germany) in a $50 \mu \mathrm{l}$ reaction volume containing $1 \mathrm{X}$ PCR buffer with $1.8 \mathrm{mM} \mathrm{MgCl}_{2}, 0.2 \mathrm{mM}$ dNTPs, $2.5 \mathrm{U}$ High Fidelity polymerase, $0.2 \mu \mathrm{M}$ of each primer and $100 \mathrm{ng}$ of template DNA. The PCR reactions were carried out in a thermal cycler (Biometra $\mathrm{GmbH}$, Germany) with the following cycling conditions: initial denaturation $\left(95^{\circ} \mathrm{C}, 10 \mathrm{~min}\right)$ followed by 30 cycles of denaturation $\left(95^{\circ} \mathrm{C}, 45 \mathrm{~s}\right)$, annealing $\left(57^{\circ} \mathrm{C}, 60 \mathrm{~s}\right)$, and elongation $\left(72^{\circ} \mathrm{C}, 45 \mathrm{~s}\right)$, ended with a final extension $\left(72^{\circ} \mathrm{C}, 10 \mathrm{~min}\right)$. The primers were linked to unique identifiers (MIDs) for multiplexing purpose, to a four base library key and to an adaptor site according the instructions of Roche. All PCR products were purified with AMPure Beads (Beckman Coulter, Germany) and subsequently quantified with the Quant-iT PicoGreen dsDNA Assay Kit (Invitrogen, Germany). Amplicon length of 550 bp was determined with a Bioanalyzer 2100 device using a DNA 7500 chip (Agilent Technologies, Germany). All generated amplicons for each sample were pooled in equal concentration. The following emulsion PCR and sequencing of the pool was performed according to Roche's recommendations for amplicons.

An initial signal processing for amplicons was performed with the software GSRunProcessor v.2.6 (Roche, Penzberg, Germany). Subsequently data were analyzed using the software MOTHUR v.1.27.0 (www.mothur.org Schloss et al., 2009) and the online tool FunGene (http://fungene.cme.msu.edu//FunGenePipeline/ as of 2013-07-01, Cole et al., 2009).

For analyzing the community of bacteria harboring alkB gene fragments, all forward sequencing data was first trimmed and denoised using the software MOTHUR following the data analysis as described by Schloss et al. (2011). For data analysis, each sample in the pool was identified by its unique MID. Only sequencing reads longer than $200 \mathrm{bp}$ were further processed starting with the dereplicator tool provided by FunGene to remove duplicate sequences. Table S1 (supplementary data) summarizes the number of reads before and after trimming as well as the average read lengths. Chimeric sequences were identified by using UCHIME (Edgar et al., 2011) implemented in the FunGene pipeline and ignored for further analysis. DNA sequences were translated into amino acid sequences and frame shift errors were corrected. After 
aligning the amino acid sequences by using the HMMER3 algorithm based on the profile hidden markov models (Finn et al., 2011) the sequences were clustered to Operational Taxonomic Units (OTUs, 97\% sequence identity) and representative amino acid sequences for each cluster were calculated. Rarefaction curves were created and evenness was calculated according to Shannon (1948). With the software R v.2.13.1 a heat map of the most abundant OTUs containing at least 50 sequences was calculated to determine which OTUs are part of the bacterial communities of each sample. Representative amino acid sequences of the OTUs presented in the heat map were identified via a NCBI BLASTP search against the non-redundant protein sequences GenBank database. All sequences gained from amplicon sequencing were submitted to the sequence read archive (SRA) of GenBank and can be found under the accession number SRP029181.

The phylogenetic analysis based on the alkB gene reference database provided by FunGene which contains at present 2012 sequences for this gene. Based on these reference sequences, a phylogenetic tree on amino acid level was constructed using the maximum parsimony algorithm implemented in the software package ARB (Ludwig et al., 2004). Only those 1380 reference sequences that are flanked by the alkB primers alkB-1f and alkB-1r were considered. Representative sequences of each OTU except those consisting of singletons were aligned to the reference sequences and added to the tree using the parsimony algorithm implemented in ARB. To make the tree more concise, sequences closely related to reference sequences were grouped to clusters. If necessary, amino acid sequences of specific clusters were identified performing a BLASTP search as described above.

\section{STATISTICAL ANALYSIS}

Statistical analysis of quantitative real-time PCR was done performing a variance analysis with treatments and sampling time points as independent factors. Variance homogeneity was tested with the coefficient of Levene. Testing significant differences between the treatments and sampling time points was carried out using a Post-hoc test following the Tukey method. All significant differences were calculated based on ANOVA analysis with $p$-values $<0.05$ and performed with SPSS v11 (SPSS Inc., USA).

Statistical analysis of the 454 data was performed with the software R v2.13.1 (http://www.R-project.org/) based on a dissimilarity matrix calculated according to the Yue and Clayton theta index of OTUs (containing at least 10 sequences) assigned to each sample. Multivariate statistics was calculated using the packages "vegan" with data transformed by Hellinger (Ramette, 2007) and similarity of bacterial communities was then determined by principal component analysis based on the dissimilarity matrix. Using the tool "adonis" provided by the vegan package, a permutational multivariate analysis of variance (PERMANOVA) was performed based on Euclidean distance calculations.

\section{RESULTS}

\section{ALKANE DYNAMICS}

The amount of alkanes in the original soil was in the range of $800-850 \mathrm{mg} / \mathrm{kg}$ (Table S2). During the incubation period the alkane concentration decreased in all treatments (also in the control treatments without compost addition); however, the compost addition resulted in higher degradation rates compared to the controls. Whereas after 12 weeks of incubation in the control microcosms concentration of alkanes was reduced to about $640 \mathrm{mg} / \mathrm{kg}$, in the soil samples amended with compost concentrations of alkanes were measured in the range of $500-540 \mathrm{mg} / \mathrm{kg}$. A differing influence of the two compost types was not visible.

\section{ABUNDANCE OF alkB GENES IN SOIL}

As a result of the increase in microbial biomass after compost addition to the soil samples, also alkB gene copy numbers were higher in the treatments amended with compost compared to the control treatments (data not shown). To investigate if the compost addition stimulated $a l k B$ harboring microbes more than others, data were related to the amount of extracted DNA, which was used as a proxy for microbial biomass. The number of alkB gene copies in all treatments ranged from $7.65 \times 10^{5}$ to $1.35 \times 10^{7}$ copies ng DNA ${ }^{-1}$ (Figure 1). For the treatments with control soil without amendment of compost, gene copy numbers decreased over time from $7.92 \times 10^{6}$ copies $n g \mathrm{DNA}^{-1}$ at the beginning of the experiment $(0$ weeks $)$ to $7.65 \times 10^{5}$ copies/ng DNA after 36 weeks. In contrast in both treatments with compost addition the number of alkB gene copies was constant over the experimental period of 36 weeks or even slightly increased and ranged from $5.59 \times 10^{6}$ copies/ng DNA (soil $+\mathrm{C} 1$ ) to $9.79 \times 10^{6}$ copies/ng DNA (soil + C2). Except for the sampling time point after 6 weeks of incubation, where gene copy numbers between both treatments amended with compost $\mathrm{C} 1$ or $\mathrm{C} 2$ did not differ, at all other time points alkB gene copy numbers in treatments with compost C2 were significantly higher compared to samples where compost $\mathrm{C} 1$ has been added.

\section{DIVERSITY OF alkB GENES IN SOIL}

Altogether, 29,822 high quality alkB gene fragment sequences were obtained from 454 sequencing with an average of 828

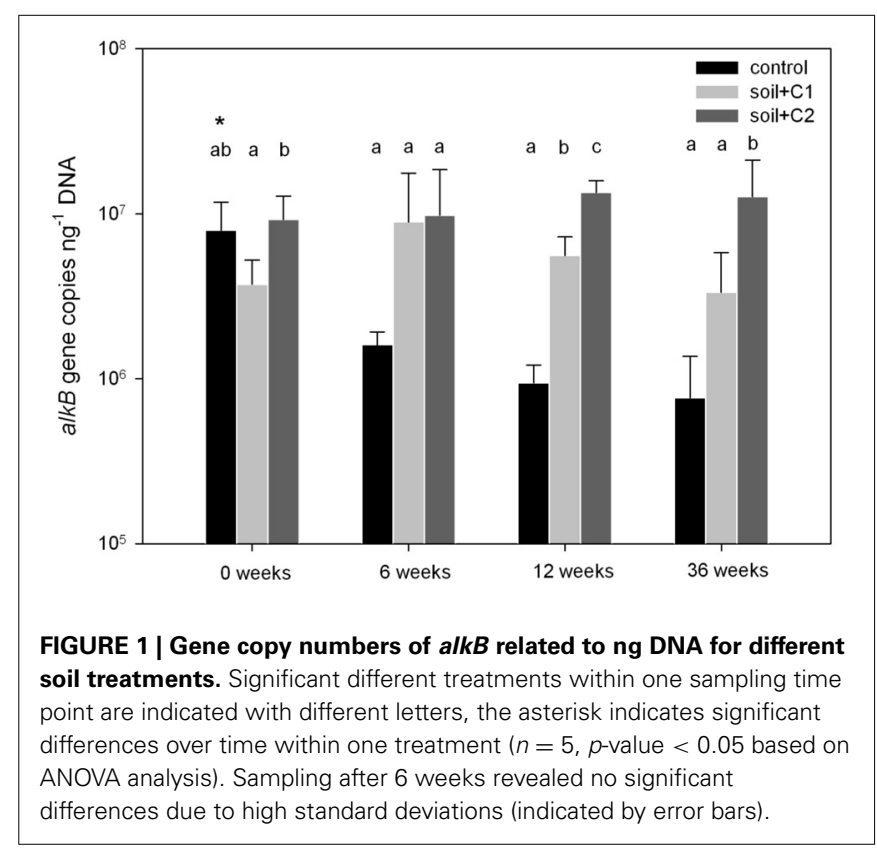


sequences per sample. As shown in Figure 2, in general evenness of alkB genes in all treatments, independent from the sampling time point, was high and ranged from 0.95 to 0.99 . Significant differences in evenness were only visible in soil samples where

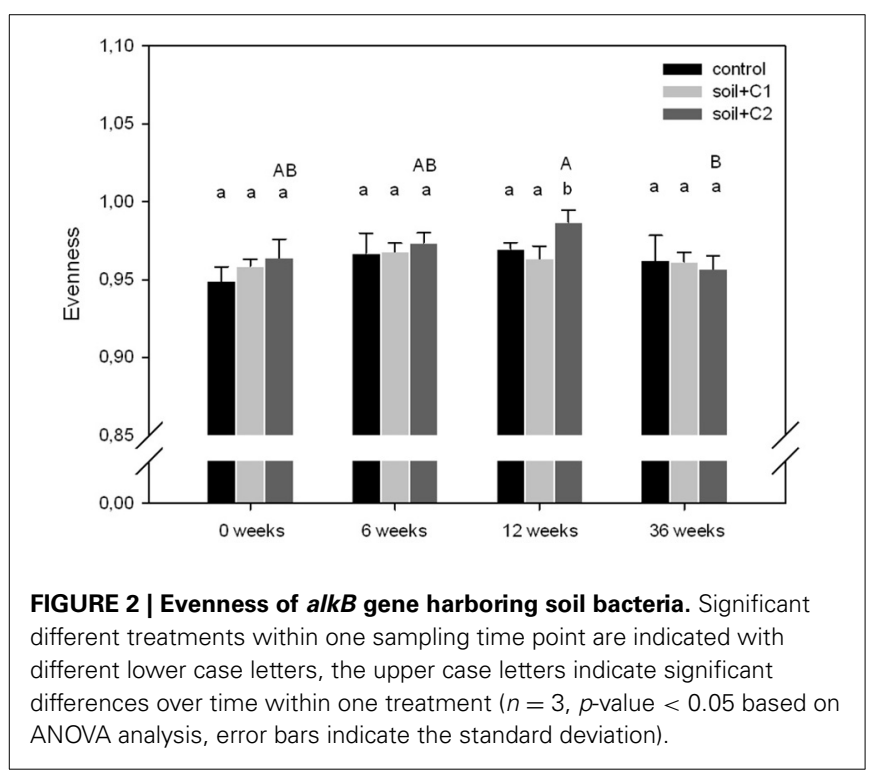

compost C2 has been added, with increased values at the sampling time points 0,6 , and 12 weeks and reduced values after 36 weeks of incubation compared to the other treatments.

Rarefaction curve analysis revealed a constant number of around 400 OTUs in the control samples over time. In contrast an increasing number of OTUs was observed over time in soil samples from treatments where compost $\mathrm{C} 1$, respectively, $\mathrm{C} 2$ has been added with almost 800 OTUs after 36 weeks of incubation in both treatments. Thus, whereas at the beginning of the experiment the number of sequenced reads was sufficient to reach saturation for all samples, for treatments where compost has been amended after 36 no plateau could be reached when the number of reads was plotted against the number of OTUs (Figure 3).

The similarity of alkB genes based on a principle component (PC) analysis is visualized in Figure 4. Mainly at later sampling time points PC 1 separates well the control soil from both soils with compost amendments, whereas PC 2 differentiates the soil mixed with old compost (soil $+\mathrm{C} 1$ ) from the soil amended with young compost (soil $+\mathrm{C} 2$ ). PERMANOVA revealed that incubation time as well as the compost type significantly influences the bacterial diversity (both $p$-values $<0.001$ ), Table 1 .

\section{PHYLOGENY OF alkB HARBORING SOIL BACTERIA}

Out of 29,822 high quality alkB gene fragment sequences 9051 OTUs were defined based on $97 \%$ sequence identities. For further

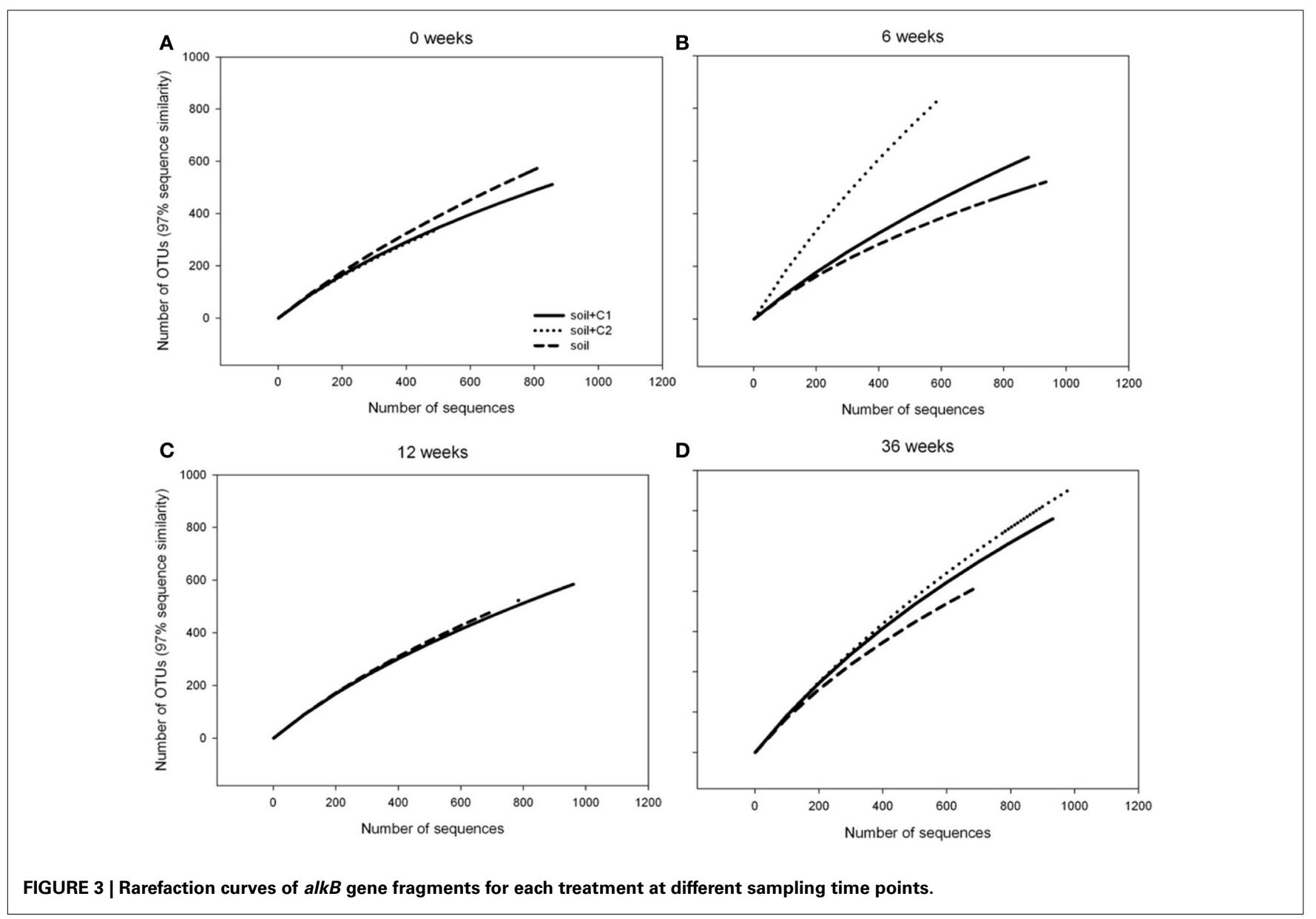




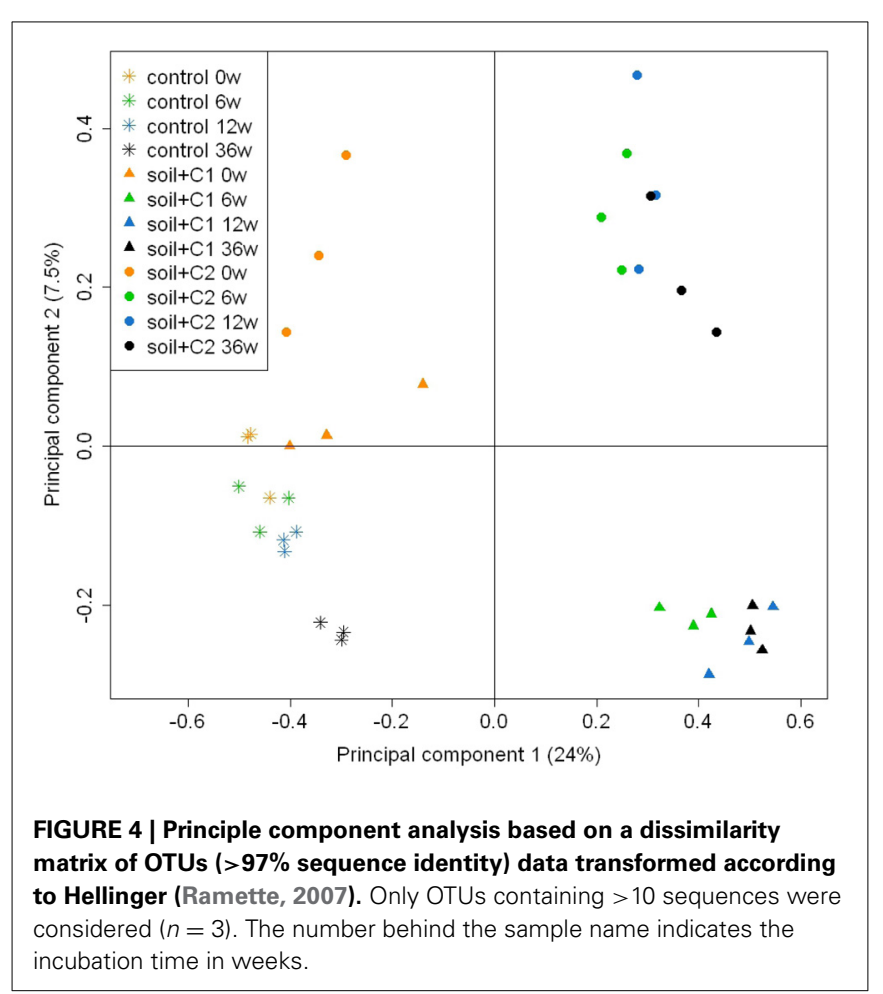

analysis only those OTUs were considered, that consist of at least two sequences and were longer than 100 amino acids in length. Thus, 3124 representative sequences were included into the phylogenetic analysis using the ARB software. Most of these sequences were assigned to Actinobacteria (30\%), followed by $y-$ proteobacteria (19\%) and Bacilli (17\%). $\alpha$ and $\beta$-proteobacteria represented 9 and 1\%, respectively, (Table 2). About 24\% (749 sequences) of the sequences were assigned to uncultured bacteria. Overall 27 clusters could be defined (Figure 5). The analysis of the generated heatmaps indicated low variability between the replicates. Control soils and soils amended with compost $\mathrm{C} 1$ and C2 clustered closely together at day 0 . In the control soil only small shifts were visible in the first 6 weeks of incubation. In contrast in samples with compost amendments the structure of alkB harboring bacteria changed more pronounced resulting in the formation of clearly separated cluster compared to day 0 . Interestingly diversity of alkB harboring bacteria was different samples amended with compost $\mathrm{C} 1$ or $\mathrm{C} 2$.

Sequences detected in the control soil were dominating clusters H (Acetobacter sp.), I (uncultured bacteria), J (Pseudomonas sp.), K (Thalassolituus sp.), M (Pseudomonas sp.), N (Bacillus sp.), $\mathrm{O}$ (Bacillus sp.), P2, P3, W (uncultured bacteria), X (Geobacillus sp.), and Y (Acinetobacter sp.). Overall sequences from the control soil could be found also in six of the other clusters; however here the number of sequences was low (Figure 6) and significantly increased by compost addition [for example sequences assigned to cluster B and E (Rhodococcus sp.) or cluster F (Sagittula sp.)]. The clusters D (Shewanella sp.), L (Microscilla sp.), Q, R (Agrobacterium sp.), S (Hydrocarboniphaga sp.), T and V (uncultured bacteria) contained exclusively sequences detected in soil amended with compost. A specific influence of the different
Table 1 | PERMANOVA results of 454 data analysis.

\begin{tabular}{lcccccc}
\hline & $\boldsymbol{D f}$ & $\begin{array}{c}\text { Sum of } \\
\text { squares }\end{array}$ & $\begin{array}{c}\text { Mean of } \\
\text { squares }\end{array}$ & $\boldsymbol{F}$ Model & $\boldsymbol{R}^{\mathbf{2}}$ & $\boldsymbol{P}$-value \\
\hline Compost type & 2 & 5.27 & 2.635 & 5.43 & 0.231 & 0.001 \\
Incubation time & 1 & 2.05 & 2.050 & 4.22 & 0.090 & 0.001 \\
\hline
\end{tabular}

compost types used was only visible for sequences from cluster $\mathrm{L}$ and $\mathrm{S}$ which were exclusively detected in samples from soil amended with compost C2.

Detailed information about the distribution of the sequences in the phylogenetic tree at the different time points of sampling is summarized in Tables S3, S4. Whereas in control soils at all time point of sampling mainly sequences assigned to Gram positive bacteria related to Bacilli as well as $\gamma$-proteobacteria were identified, in soil samples amended with compost C1 and C2 the maximal number of representative sequences could be assigned to Actinobacteria after 6 weeks of incubation at all later sampling time points. In soil samples amended with compost C2 also a remarkable high number of sequences associated to Cytophaga mainly at the time point after compost addition could be identified, which was significantly reduced at the other sampling time points.

\section{DISCUSSION}

In this study we analyzed in a microcosm experiment the effects of the amendment of different composts with contrasting maturation stage on the abundance and diversity of alkB harboring bacteria in a soil contaminated with hydrocarbons. Previous studies revealed that alkB related sequences are present in a wide range of soil and water derived bacteria, such as Acinetobacter, Alcanivorax, Burkholderia, Mycobacterium, Pseudomonas, Rhodococcus and others (Van Beilen and Funhoff, 2007; Pérez-De-Mora et al., 2011). Furthermore, many alkB harboring bacteria (e.g., Mycobacterium and Nocardia) carry in addition to the alk operon genes like almA which encodes for an enzyme that is involved in degrading of alkanes with a chain length of $\mathrm{C}_{32}$ and longer (Feng et al., 2007). Thus, alkB seems to be not only a good marker to study the potential to degrade alkanes with a chain length between C5 and C16 (Van Beilen and Funhoff, 2005; Rojo, 2009), but also the general indicator for alkane degradation in the environment.

However, the number of alkB harboring operons per cell differs between different bacterial species. For bacteria of the genus Rhodococcus up to seven operons per cell have been described, whereas for other bacteria (e.g., Pseudomonads) the number of operons/cell was between 1 and 2 (Heiss-Blanquet et al., 2005). This must be taken into account when the results of this study are interpreted mainly in terms of increasing abundance of alkB harboring bacteria in the response of compost addition.

Obviously compost may have two different effects. On the one hand it might provide a suitable substrate to stimulate the growth of microbes from the original soil capable to degrade alkanes, like it was shown for Actinobacteria, which start to become highly abundant 6 weeks after compost amendment independent from the type of compost. As in addition no shift in diversity of 
Table 2 | Distribution of alkB gene fragments over all samples.

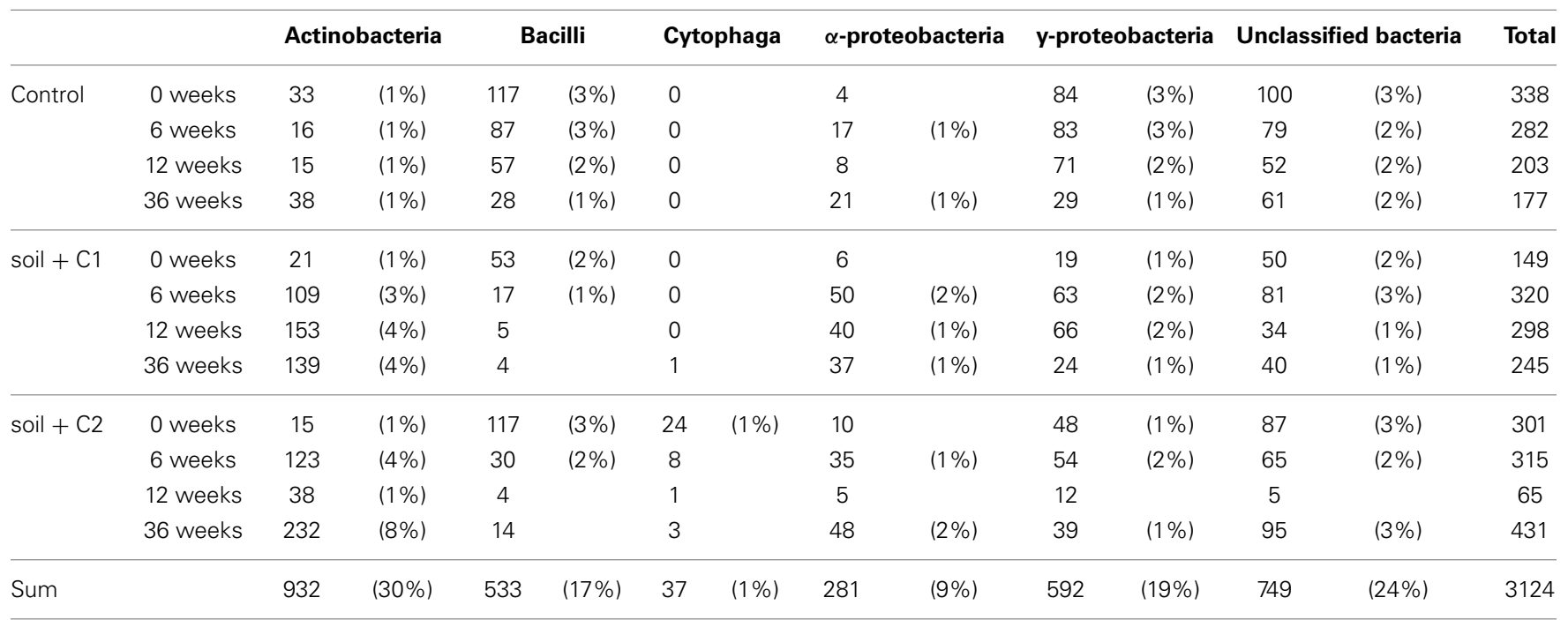

Only sequences assigned to specific clusters are considered. Numbers in parentheses indicate the percentage of the corresponding class for each sample.

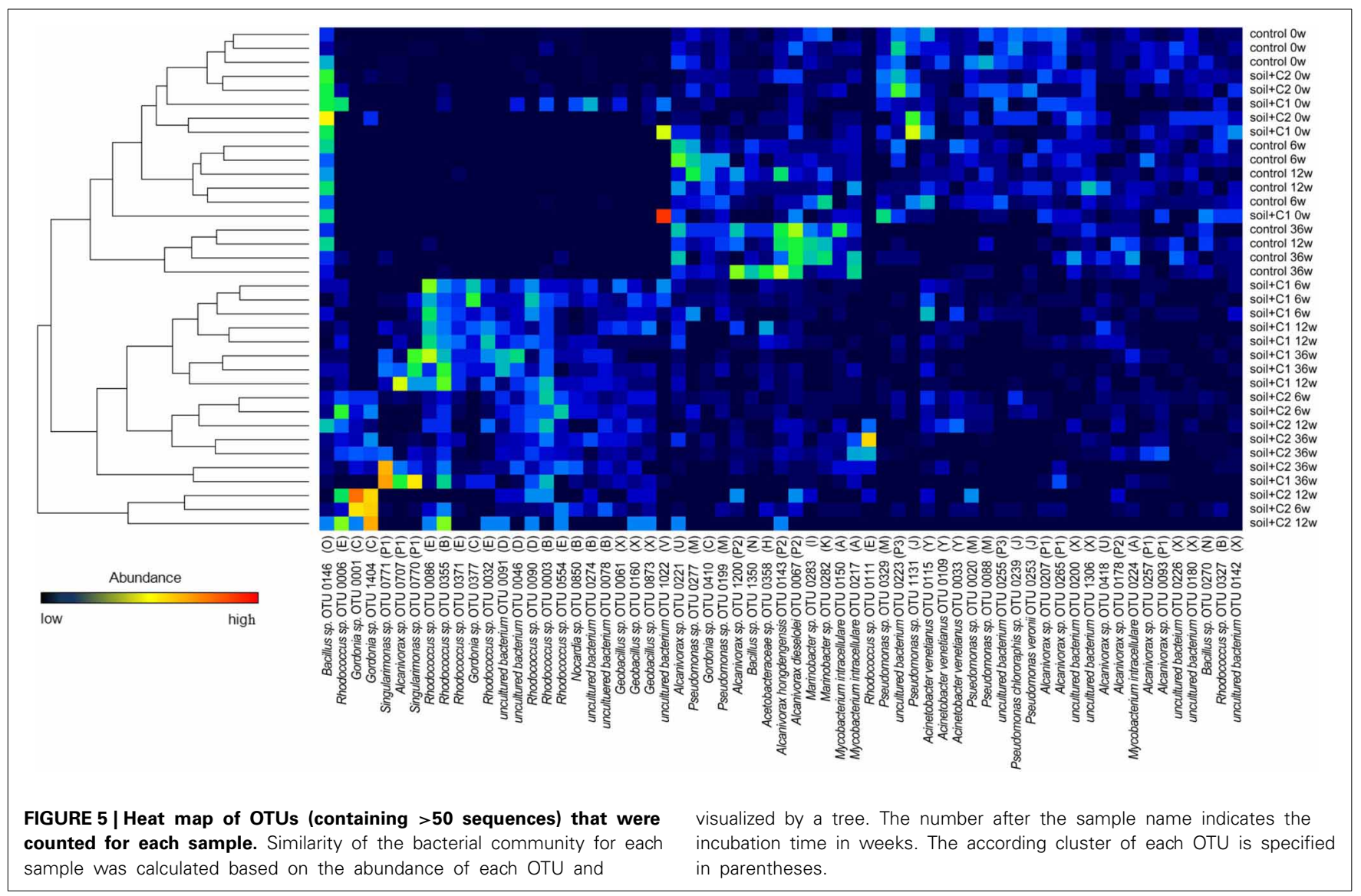

this group was observed, we may assume here a growth stimulation effect. Here our results correspond to other observations, that litter material stimulates the abundance of alkB harboring communities in soil as well induces changes in diversity (Schulz et al., 2012). Furthermore, the introduced amounts of nutrients may stimulate co-degradation of alkanes in soil and changes sorption properties of alkanes to soil particles. For example several Pseudomonas species in soil are well known for producing biosurfactants like rhamnolipids (P. aeruginosa Kumar et al., 2008, P. fluorescens Abouseoud et al., 2008) that enhance hydrocarbon 


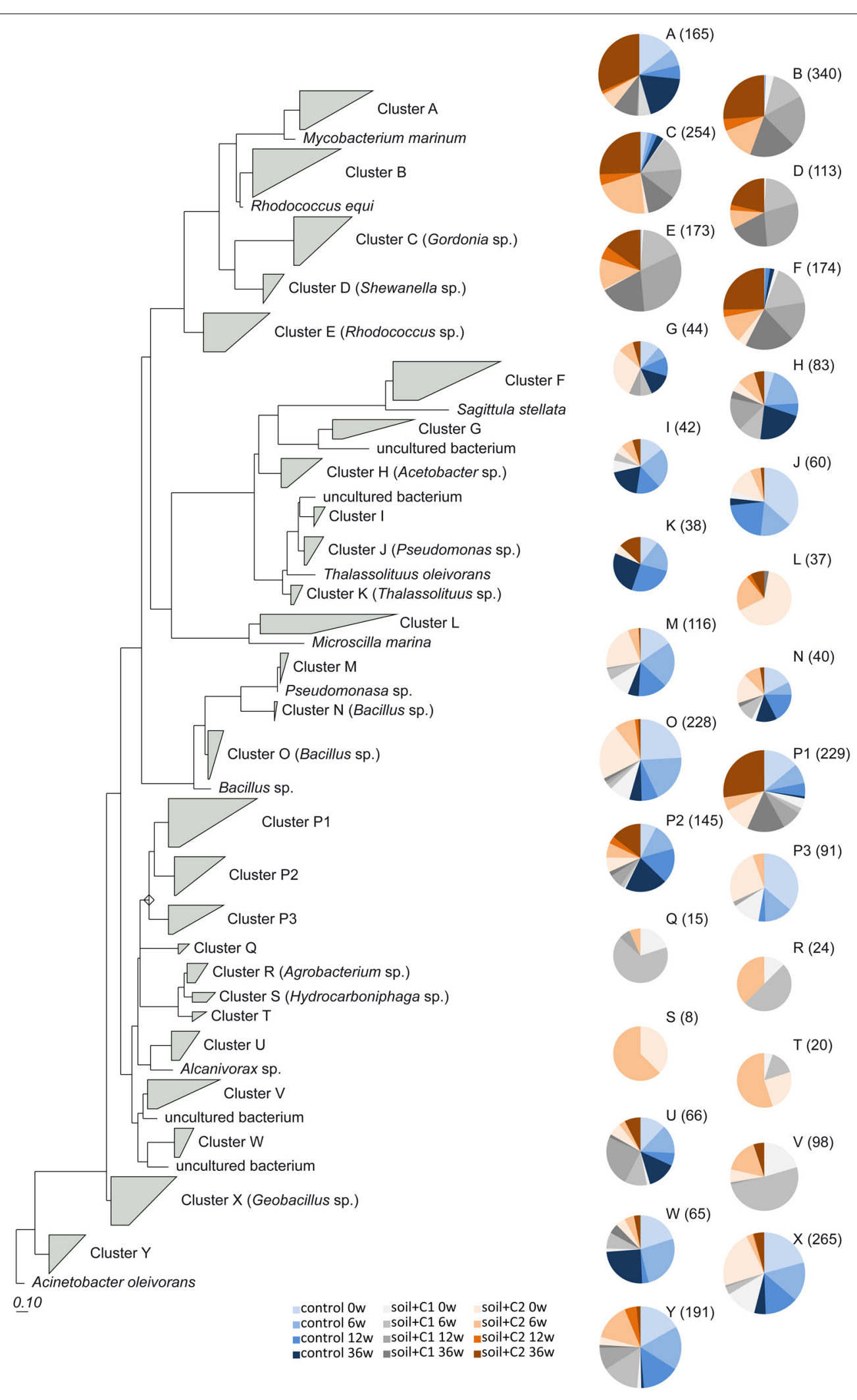

FIGURE 6 | Phylogenetic tree calculated with the maximum parsimony algorithm based on the reference sequences on amino acids of alkB gene fragments provided by RDP. 454 sequencing amplicons were included. For conciseness, sequences closely related to reference sequences were grouped into clusters from A to Y. Bold numbers indicate the number of sequences within the cluster. If the reference sequence is within the same cluster, the according name is given in parentheses. The number of representative sequences of each sample is indicated with pie charts for each cluster. Different size of pie charts reflects the total number of sequences (given in parentheses) for each cluster. 
uptake through emulsification via decreasing the surface tension and forming micelles (Das and Chandran, 2011).

On the other hand, for other groups mainly Cytophaga related bacteria an effect was only visible directly after compost addition, indicating that the introduced microbes by compost were not able to survive in the soil environment. In contrast other introduced bacteria, mainly from related to proteobacteria could obviously successfully establish in soil. Sequencing of alkB gene fragments revealed that those organisms are closely related to common soil bacteria like members of Agrobacterium. Some of the representative sequences are closely related to genera known for their appearance in alkane rich environments. For example a number of sequences obtained from soil samples amended with compost clustered around the genus Hydrocarboniphaga, a member of $\gamma$-proteobacteria. (Palleroni et al., 2004) cultivated the strain Hydrocarboniphaga effusa DSM $16095^{\mathrm{T}}$ successfully that originally was isolated from soil contaminated with heavy fuel oil hydrocarbons in New Jersey. Recently, Liu et al. (2011) linked another strain, Hydrocarboniphaga daqingensis NBRC $104238^{\mathrm{T}}$ to degradation of alkanes with medium chain length $\left(\mathrm{C}_{9}-\mathrm{C}_{17}\right)$. Additionally, some representative sequences from soils with amendment of $\mathrm{C} 1$ or $\mathrm{C} 2$ could be linked to the genus Thalassolituus, which is closely related to alkB sequences of Pseudomonas. T. oleivorans strain DSM 14913, a strain able degrade alkanes in marine environments described by Yakimov et al. (2004) and recently fully sequenced (Golyshin et al., 2013).

Also for most other alkB sequences found in our study which were partly being present also in the original soil samples without compost amendment like Singularimonas variicoloris, Mycobacterium sp. Nocardia sp. Pseudomonas veronii or Acinetobacter venetianus alkane degradation has been proven (Onaca et al., 2007; Friedrich and Lipski, 2008; Luckarift et al., 2011; Wang and Shao, 2013). Some of them (e.g., Mycobacterium and Nocardia) harbor in addition to the alk operon genes like $\operatorname{alm} A$ which encodes for an enzyme that is involved in degrading of alkanes with a chain length of $\mathrm{C}_{32}$ and longer (Feng et al., 2007).

Although our study clearly indicates that the amendment of composts to petroleum contaminated soils have pronounced effects of the abundance and diversity of alkB harboring bacteria, future studies must prove that this concept will also lead an enhanced stimulation of alkane degraders (based on mRNA analysis) and subsequently to enhanced biodegradation rates of alkanes in the particular soils. In addition it is well known that mainly not well maturated composts contain a large number of bacteria with (human) pathogenic potential. As our study could prove that probably some bacteria from compost are able to colonize the soil matrix, thus more data is needed also on this aspect before the method of compost application for bioremediation can be applied on a broader range.

\section{SUPPLEMENTARY MATERIAL}

The Supplementary Material for this article can be found online at: http://www.frontiersin.org/journal/10.3389/fmicb. 2014.00096/abstract

Table S1 | Summary of sequence processing.
Table S2 | Average total alkane concentrations ( $\mathrm{mg} / \mathbf{k g}$ ) with standard errors $(n=3)$. Different letters indicate statistically significant difference between averages according to Tukey's multiple comparison test $(P \leq 0.05)$.

Table S3 | alkB gene fragments of amplicon sequencing were included into a phylogenetic ARB tree on amino acid level. Sequences closely related to reference sequences were grouped to clusters. Dashes (-) indicate sequences that could not be assigned to any specific cluster.

Table S4 | Distribution of representative sequences within each cluster for each sample as shown in the pie charts presented in Figure 6. Numbers are given in percentages.

\section{REFERENCES}

Abouseoud, M., Yataghene, A., Amrane, A., and Maachi, R. (2008). Biosurfactant production by free and alginate entrapped cells of Pseudomonas fluorescens. J. Ind. Microbiol. Biotechnol. 35, 1303-1308. doi: 10.1007/s10295-0080411-0

Andria, V., Reichenauer, T., and Sessitisch, A. (2009). Expression of alkane monooxygenase $(a l k B)$ genes by plant-associated bacteria in the rhizosphere and endosphere of Italian ryegrass (Lolium multiflorum L.) grown in diesel contaminated soil. Environ. Pollut. 157, 3347-3350. doi: 10.1016/j.envpol.2009.08.023

Ayala, M., and Torres, E. (2004). Enzymatic activation of alkanes: constraints and prospective. Appl. Catal. A Gen. 272, 1-13. doi: 10.1016/j.apcata.2004.05.046

Beaudin, N., Caron, R. F., Legros, R., Ramsay, J., and Ramsay, B. (1999). Identification of the key factors affecting composting of a weathered hydrocarbon-contaminated soil. Biodegradation 10, 127-133. doi: 10.1023/A:1008365832031

Cole, J. R., Wang, Q., Cardenas, E., Fish, J., Chai, B., Farris, R. J., et al. (2009). The ribosomal database project: improved alignments and new tools for rRNA analysis. Nucleic Acids Res. 37, D141-D145. doi: 10.1093/nar/gkn879

Das, N., and Chandran, P. (2011). Microbial degradation of petroleum hydrocarbon contaminants: an overview. Biotechnol. Res. Int. 2011, 941810-941810. doi: $10.4061 / 2011 / 941810$

Dubbels, B. L., Sayavedra-Soto, L. A., and Arp, D. J. (2007). Butane monooxygenase of 'Pseudomonas butanovora': purification and biochemical characterization of a terminal-alkane hydroxylating diiron monooxygenase. Microbiology 153, 1808-1816. doi: 10.1099/mic.0.2006/004960-0

Edgar, R. C., Haas, B. J., Clemente, J. C., Quince, C., and Knight, R. (2011). UCHIME improves sensitivity and speed of chimera detection. Bioinformatics 27, 2194-2200. doi: 10.1093/bioinformatics/btr381

Eglinton, G., Hamilton, R. J., Raphael, R. A., and Gonzalez, A. G. (1962). Hydrocarbon constituents of the wax coatings of plant leaves: a taxonomic survey. Phytochemistry 1, 89-102. doi: 10.1016/S0031-9422(00)88006-1

Feng, L., Wang, W., Cheng, J., Ren, Y., Zhao, G., Gao, C., et al. (2007). Genome and proteome of long-chain alkane degrading Geobacillus thermodenitrificans NG80-2 isolated from a deep-subsurface oil reservoir. Proc. Natl. Acad. Sci. U.S.A. 104, 5602-5607. doi: 10.1073/pnas.0609650104

Finn, R. D., Clements, J., and Eddy, S. R. (2011). HMMER web server: interactive sequence similarity searching. Nucleic Acids Res. 39, W29-W37. doi: 10.1093/nar/gkr367

Fisher, D. J., Holloway, P. J., and Richmond, D. V. (1972). Fatty acid and hydrocarbon constituents of the surface and wall lipids of some fungal spores. J. Gen. Microbiol. 72, 71-78. doi: 10.1099/00221287-72-1-71

Friedrich, M. L. M., and Lipski, A. (2008). Alkanibacter difficilis gen. nov., sp. nov. and Singularimonas variicoloris gen. nov., sp. nov., hexane-degrading bacteria isolated from a hexane-treated biofilter. Int. J. Syst. Evol. Microbiol. 58, 2324-2329. doi: 10.1099/ijs.0.65517-0

Giebler, J., Wick, L. Y., Schloter, M., Harms, H., and Chatzinotas, A. (2013). Evaluating the assignment of alkB terminal restriction fragments and sequence types to distinct bacterial taxa. Appl. Environ. Microbiol. 79, 3129-3132. doi: 10.1128/AEM.04028-12

Golyshin, P. N., Werner, J., Chernikova, T. N., Tran, H., Ferrer, M., Yakimov, M. M., et al. (2013). Genome sequence of Thalassolituus oleivorans MIL-1 (DSM 14913T). Genome Announc. 1:e0014113. doi: 10.1128/genomeA.00141-13 
Heiss-Blanquet, S., Beinoit, Y., Marechaux, C., and Monot, F. (2005). Assessing the role of alkane hydroxylase genotypes in environmental samples by competitive PCR. J. Appl. Microbiol. 99, 1392-1403. doi: 10.1111/j.1365-2672.2005.02715.x

Jiang, H., Chen, Y., Jiang, P., Zhang, C., Smith, T., and Murell, J. (2010). Methanotrophs: multifunctional bacteria with promising applications in environmental bioengineering. Biochem. Eng. J. 49, 277-288. doi: 10.1016/j.bej.2010.01.003

Ji, Y., Mao, G., Wang, Y., and Bartlam, M. (2013). Crystallization and preliminary $\mathrm{X}$-ray characterization of an NAD (P)-dependent butanol dehydrogenase A from Geobacillus thermodenitrificans NG80-2. Acta Crystallogr. Sect. F. Struct. Biol. Cryst. Commun. 69, 184-187. doi: 10.1107/S1744309113000766

Keeling, A. A., Mullett, J. A. J., and Paton, I. K. (1994). GC-mass spectrometry of refuse-derived composts. Soil Biol. Biochem. 26, 773-776. doi: 10.1016/00380717(94)90272-0

Kloos, K., Munch, J. C., and Schloter, M. (2006). A new method for the detection of alkane-monooxygenase homologous genes (alkB) in soils based on PCR-hybridization. J. Microbiol. Methods 66, 486-496. doi: 10.1016/j.mimet.2006.01.014

Kumar, M., León, V., Sisto Materano, A., Ilzins, O., and Luis, L. (2008). Biosurfactant production and hydrocarbon-degradation by halotolerant and thermotolerant Pseudomonas sp. J. Basic Microbiol. 24, 1047-1057. doi: 10.1007/s11274-007-9574-5

Liu, Y., Song, X.-F., Jiang, J.-T., Liu, Y.-H., Xu, C.-J., Li, H., et al. (2011). Hydrocarboniphaga daqingensis sp. nov., isolated from a freshwater lake. Int. J. Syst. Evol. Microbiol. 61, 408-411. doi: 10.1099/ijs.0.019380-0

Luckarift, H. R., Sizemore, S. R., Farrington, K. E., Fulmer, P. A., Biffinger, J. C., Nadeau, L. J., et al. (2011). Biodegradation of medium chain hydrocarbons by Acinetobacter venetianus $2 \mathrm{AW}$ immobilized to hair-based adsorbent mats. Biotechnol. Prog. 27, 1580-1587. doi: 10.1002/btpr.701

Ludwig, W., Strunk, O., Westram, R., Richter, L., Meier, H., Yadhukumar, B., et al. (2004). ARB: a software environment for sequence data. Nucleic Acids Res. 32, 1363-1371. doi: 10.1093/nar/gkh293

Mori, K. (2007). The Synthesis of Insect Pheromones, 1979-1989. Hoboken, NJ: John Wiley and Sons, Inc.

Onaca, C., Kieninger, M., Engesser, K.-H., and Altenbuchner, J. (2007). Degradation of alkyl methyl ketones by Pseudomonas veronii MEK700. J. Bacteriol. 189, 3759-3767. doi: 10.1128/JB.01279-06

OPEC. (2012). Annual Statistical Bulletin. Available online at: http://www. opec.org/opec_web/static_files_project/media/downloads/publications/ASB20 12.pdf

Oró, J., Laseter, J. L., and Weber, D. (1966). Alkanes in fungal spores. Science 154, 399-400. doi: 10.1126/science.154.3747.399

Palleroni, N. J., Port, A. M., Chang, H.-K., and Zylstra, G. J. (2004). Hydrocarboniphaga effusa gen. nov., sp. nov., a novel member of the gammaProteobacteria active in alkane and aromatic hydrocarbon degradation. Int. J. Syst. Evol. Microbiol. 54, 1203-1207. doi: 10.1099/ijs.0.03016-0

Pérez-De-Mora, A., Engel, M., and Schloter, M. (2011). Abundance and diversity of $\mathrm{n}$-alkane-degrading bacteria in a forest soil co-contaminated with hydrocarbons and metals: a molecular study on alkB homologous genes. Microb. Ecol. 62, 959-972. doi: 10.1007/s00248-011-9858-z

Pinedo, J., Ibanez, R., Lijzen, J. P., and Irabien, A. (2013). Assessment of soil pollution based on total petroleum hydrocarbons and individual oil substances. J. Environ. Manage. 130, 72-79. doi: 10.1016/j.jenvman.2013.08.048

Ramette, A. (2007). Multivariate analyses in microbial ecology. FEMS Microbiol. Ecol. 62, 142-160. doi: 10.1111/j.1574-6941.2007.00375.x

Rojo, F. (2009). Degradation of alkanes by bacteria. Environ. Microbiol. 11, 2477-2490. doi: 10.1111/j.1462-2920.2009.01948.x

Scalenghe, R., and Ferraris, S. (2009). The first forty years of a technosol. Pedosphere 19, 40-52 doi: 10.1016/S1002-0160(08)60082-X
Schloss, P. D., Gevers, D.,and Westscott, S. L. (2011). Reducing the effects of PCR amplification and sequencing artefacts on $16 \mathrm{~S}$ rRNA-based studies. PLoS ONE 6:e27310. doi: 10.1371/journal.pone.0027310

Schloss, P. D., Westcott, S. L., Ryabin, T., Hall, J. R., Hartmann, M., Hollister, E. B., et al. (2009). Introducing mothur: open-source, platform-independent, community-supported software for describing and comparing microbial communities. Appl. Environ. Microbiol. 75, 7537-7541. doi: 10.1128/AEM.01541-09

Schulz, S., Giebler, J., Chatzinotas, A., Wick, L. Y., Fetzer, I., Welzl, G., et al. (2012). Plant litter and soil type drive abundance, activity and community structure of alkB harbouring microbes in different soil compartments. ISME J. 6, 1763-1774. doi: 10.1038/ismej.2012.17

Séré, G., Schwartz, C., Ouvrard, S., Sauvage, C., Renat, J.-C., and Morel, J. L. (2008). Soil construction: a step for ecological reclamation of derelict lands. J. Soils Sediments 8, 130-136. doi: 10.1065/jss2008.03.277

Shannon, C. E. (1948). A mathematical theory of communication. Bell Syst. Tech. J. 27, 379-423. doi: 10.1002/j.1538-7305.1948.tb01338.x

SOER. (2010). The European Environment-State and Outlook 2010. European Environment Agency. doi: 10.2800/58866. Available online at: http://www.eea.europa.eu/soer

Steffan, R. J., McClay, K., Vainberg, S., Condee, C. W., and Zhang, D. (1997). Biodegradation of the gasoline oxygenates methyl tert-butyl ether, ethyl tertbutyl ether, and tert-amyl methyl ether by propane-oxidizing bacteria. Appl. Environ. Microbiol. 63, 4216-4222.

Van Beilen, J. B., and Funhoff, E. G. (2005). Expanding the alkane oxygenase toolbox: new enzymes and applications. Curr. Opin. Biotechnol. 16, 308-314. doi: 10.1016/j.copbio.2005.04.005

Van Beilen, J. B., and Funhoff, E. G. (2007). Alkane hydroxylases involved in microbial alkane degradation. Appl. Microbiol. Biotechnol. 74, 13-21. doi: 10.1007/s00253-006-0748-0

Van Gestel, K., Mergaert, J., Swings, J., Coosemans, J., and Ryckeboer, J. (2003). Bioremediation of diesel oil-contaminated soil by composting with biowaste. Environ. Pollut. 125, 361-368. doi: 10.1016/S0269-7491(03)00109-X

Wang, W., and Shao, Z. (2013). Enzymes and genes involved in aerobic alkane degradation. Front. Microbiol. 4:116. doi: 10.3389/fmicb.2013.00116

Yakimov, M. M., Giuliano, L., Denaro, R., Crisafi, E., Chernikova, T. N., Abraham, W.-R., et al. (2004). Thalassolituus oleivorans gen. nov., sp. nov., a novel marine bacterium that obligately utilizes hydrocarbons. Int. J. Syst. Evol. Microbiol. 54, 141-148. doi: 10.1099/ijs.0.02424-0

Conflict of Interest Statement: The authors declare that the research was conducted in the absence of any commercial or financial relationships that could be construed as a potential conflict of interest.

Received: 01 September 2013; accepted: 21 February 2014; published online: 13 March 2014.

Citation: Wallisch S, Gril T, Dong X, Welzl G, Bruns C, Heath E, Engel M, Suhadolc M and Schloter $M$ (2014) Effects of different compost amendments on the abundance and composition of alkB harboring bacterial communities in a soil under industrial use contaminated with hydrocarbons. Front. Microbiol. 5:96. doi: 10.3389/fmicb. 2014.00096

This article was submitted to Terrestrial Microbiology, a section of the journal Frontiers in Microbiology.

Copyright (c) 2014 Wallisch, Gril, Dong, Welzl, Bruns, Heath, Engel, Suhadolc and Schloter. This is an open-access article distributed under the terms of the Creative Commons Attribution License (CC BY). The use, distribution or reproduction in other forums is permitted, provided the original author(s) or licensor are credited and that the original publication in this journal is cited, in accordance with accepted academic practice. No use, distribution or reproduction is permitted which does not comply with these terms. 